\title{
Problems and Solutions: A Cultural and Textual Approach to the E-C Translation of Response to Modernity-A History of the Reform Movement in Judaism*
}

\author{
YU Jie \\ Tianjin Normal University, Tianjin, China
}

\begin{abstract}
This paper reviews the translation process of Michael Meyer's Response to Modernity-A History of the Reform Movement in Judaism. As the translator of this book, the author points out the problems confronted in the course of translation from the lexical, phrasal, sentential, and textual levels, meanwhile provides the corresponding translating strategies to solve these difficulties. The cultural strategy bridges the gap between the original work and the target language readers while the textual approach enhances the readability of the translated version. The translation of Response to Modernity into Chinese is of significant reference value for Chinese scholars dedicated to Jewish studies.
\end{abstract}

Keywords: Response to Modernity—A History of the Reform Movement in Judaism, cultural translation, textual translation

\section{Introduction}

Response to Modernity-A History of the Reform Movement in Judaism offers a comprehensive and balanced history of the reform movement, tracing its changing configuration and self-understanding from the beginnings of modernization in late 18th century Jewish thought and practice through reform's 1970s American renewal. The writer of this book is Michael A. Meyer, a researcher in Leo Baeck Institute of New York city, who has been devoted to the study of the historical development of Judaism and was honored the Award of Moses Mendelssohn in 2015. The publication of Response to Modernity has won numerous advanced praises by various scholars. The Center for Judaic and Inter-religious Studies of Shandong University in China has initiated a project of translating Jewish cultural classics into Chinese since the very beginning of the 21st century. Michael Meyer's Response to Modernity is part of this project. The author assumes the project of translating this book into Chinese, which is of unique significance to facilitate the Jewish studies for Chinese scholars. To be able to undertake this vast translating task is a great honor for the translator on one hand but on the other it means a serious responsibility to provide a high-quality version for Chinese Jewish scholars as well as to reproduce the original information to the utmost extent.

The translation procedure of Response to Modernity can be divided into three stages: pre-translation,

\footnotetext{
* Acknowledgement: This paper is sponsored by the Training Program for Young and Mid-aged Backbone Innovation Talents in Tianjin Universities (Project No. 043-135205GC27).

YU Jie, Doctorate, Associated Professor, Foreign Language College,Tianjin Normal University.
} 
mid-translation, and post-translation. In the first stage, the translator did a substantial preparation work including a rough reading of the original work and some related translated works as well as several Jewish dictionaries and encyclopedias: A Short History of The Jewish People (Roth, 1997), Everyman's Talmud (Cohen, 1998), Modern Jewish Religious Movements-A History of Emancipation and Adjustment (Rudavsky, 2000), On Judaism (Buber, 2002), Judaism as a Civilization (Kaplan, 2002), Anti-Semitism: Past and Present (Xu, 2015), The Arab World and the Palestine Question (Chen, 2013), Dictionary Judaica (Zhou, 2004), and Encyclopedia Judaica (Xu \& Ling, 1993). The reading of these reference books lays a solid foundation for the translating work in the second stage.

\section{Problems and Solutions}

During the course of translation, the translator came across various kinds of problems and worked out the corresponding solutions according to concrete situations. The problems can be summarized from four levels according to the sequential linguistic units: word-level, phrase-level, sentence-level, and textual-level.

\section{Lexical level}

At the word-level, problems are mainly embodied in proper names, cultural terms, and neologisms. As Meyer paid particular attention to the personal qualities of its leaders of the reforming movement in Response to Modernity, a large number of personal names appear in the original work. For those well-known names, the translator adopts the conventional translation method and keep the same as the already established translated names, such as “Moses Mendelssohn” translated as “摩西・门德尔松,” which is universally agreed and acknowledged by Chinese scholars. For some unfamiliar personal names, the translator adopts transliteration adding the original spelling of the name in the brackets, especially those names which coincide with the spelling of place names. Take "Israel Jacobson" for example, it is not proper to translate it as “以色列” which coincides with the name of the country, so it is advisable to adopt transliteration as “伊斯雷尔 - 雅各布森.” Another similar example is “Saul Berlin” (1740-1794). To make it distinct from the capital city name “柏林,” the translator chooses the version of “索尔・博林”.

For proper names of places, the original work only offers the different names without providing the information on its exact administrative unit, which is necessary for the readers of the target language. In order to make up for this cognitive gap, the translator needs to exert his/her subjectivity to provide the corresponding information. For example,

Frankel was born in Prague ... He was the first rabbi in Bohemia to possess a university education ... In Teplitz, where he took up residence ... In 1836, Frankel moved to Dresden as chief rabbi for Saxony ... until he assumed the founding directorship of the Jewish Theological Seminary in Breslau in 1854. (Meyer, 1988, p. 85)

Many place names appear in this paragraph to introduce the experience of Zacharias Frankel, the ideological father of present-day Conservative Judaism. If the translator merely adopted transliteration to render the name of these places, most Chinese readers have no concepts about them. In this case, the translator combines transliteration and addition to offer a comprehensive interpretation of these place names. Taking the majority readers' geographical knowledge storage into consideration, the translator renders the marked place names into: 布拉格, 波西米亚省 (Prague: Prague: an important region in the history of Czechoslovakia), 台 普利茨小镇 (Teplitz: a small town 90 kilometers away from Prague), 德累斯顿市 (Dresden: the capital city of Saxony of Germany), 萨克森州 (Saxony) and 布雷斯劳市 (Breslau: a city in the Southwest of Poland). 
The addition of the administrative units of state, town and city is necessary for the better understanding of these foreign places for Chinese readers.

Some Judaism-specific cultural terms are another big obstacle in the course of translation, such as Haskalah, Halakhah, Haggadah, Hanukah, Succoth, Shavuoth, Passover, Rosh Hashanah, Yom Kippur, Marrano, Kraite, etc. According to Peter Newmark, cultural components tend to be transferred and explained with culturally neutral terms in informative texts (Newmark, 2001, p. 47). That is to say, translator can adopt free translation plus the necessary annotation to make clear the cultural meaning of these terms. Therefore, the above-mentioned Jewish cultural terms are rendered into 犹太启蒙运动, 犹太律法, 哈加达 (Talmudic literature that does not deal with law but is still part of Jewish tradition), 光明节, 住棚节 (a Jewish festival that takes place in autumn, during which shelters are made using natural materials), 七七节 (五旬节, a Jewish festival that takes place 50 days after the second day of Passover), 逾越节, 犹太新年, 赎罪日，马拉诺 (In medieval Spain, it refers to a Jew or Moor who converted to Christianity, especially those who professed conversion in order to avoid persecution but continued to practice their religion secretly), 圣经派信徒 respectively.

The biggest challenge at word-level are some new terms which have no Chinese equivalents either literally or freely. The translator adopts neologism methods to create a new name based on the English explanation from authoritative sources. For example, there is no precedent reference for "High Holidays." According to Wikipedia explanation, the High Holidays or High Holy Days, in Judaism, more properly known as the Yamim Noraim (Days of Awe), may mean strictly, the holidays of Rosh Hashanah (Jewish New Year) and Yom Kippur (Day of Atonement). By extension, the period of 10 days including those holidays, known also as the 10 Days of Repentance, or by a further extension, the entire 40-day penitential period in the Jewish year from Rosh Chodesh Elul to Yom Kippur, traditionally taken to represent the 40 days Moses spent on Mount Sinai before coming down with the second (replacement) set the Tablets of stone. Based on the above explanation, the translator draws a conclusion that this Jewish holiday refers either to a combination of two festivals or a period celebrating Jewish New Year, thus a new term is coined as “新年假期,” covering both the narrow and broad sense of this unique holiday instead of adopting the word-for-word translation as “高假期” with a consequence only to confuse the target language readers.

\section{Phrasal level}

As for the translation of phrases, some need to resort to the contexts to determine the exact or close meanings. In Chapter 3 of the original work, the translator met such a sentence, "It was Geiger who first took the initiative to deal with this situation" (Meyer, 1988, p. 132). If the literal translation of the phrase "this situation" is offered to readers, most probably they may be at a loss about what kind of situation this refers to. Taking the readers' acceptability into consideration, the translator resorts to the contextual information presented in the same paragraph five lines before this phrase "By the early forties the course of reform seemed chaotic” (Meyer, 1988, p. 132) and clarify the meaning of this phrase as “混乱局势.” Similar examples occur in the original work frequently. When the translator is confronted with such a phrase as "the turn of century," on most occasions, the version is enriched for readers by providing the exact information as "between the 19th and 20th century" according to the concrete contextual knowledge.

Roger E. Axtell defines false friends as "words in another language that look like the same as English words but mean entirely different things” (Fang, 2003, p. 8). There are also some false friends at phrase level 
which can easily lead to the translator's mistranslations. For example, "The creation of a new institution that would also incorporate the sought-after reforms”(Meyer, 1988, p. 173), the first version of the above marked phrase is “后来寻求的改革” which was revised into “广受欢迎的改革” after the translator consulted the dictionary to determine the accurate meaning of this compound adjective as "widely popular" rather than the combination of each individual word. For another example, "The reform movement in the 1950s condemned the prevalent practice of exacting loyalty oaths and the technique of character assassination that was stock in trade for the House Un-American Activities Committee” (Meyer, 1988, p. 365). The meanings of these two marked phrases are far from what they seem to be. For a qualified translator, responsibility is of prior importance. Collins e-dictionary explains "character assassination" as "a deliberate attempt to destroy someone's reputation, especially by criticizing them in an unfair and dishonest way when they are not present." 21st Century e-dictionary explains "stock in trade" as "tricks constantly used for some illicit purposes. Based on the explanations from these two authoritative sources and the contexts they are related to, the translator revised the version as “惯用的人格谋杀手段”.

\section{Sentential level}

Perceived from the sentence level, Meyer uses complicated and long sentences in most cases as Response to Modernity is a strictly academic work. This formal style of text type increases the difficulty in translation so far as understanding and expression are concerned (i. e., it is difficult for the translator to understand the original text on one hand and it is much more difficult to translate it into proper Chinese on the other). Considering the formal difference between English and Chinese language, the former emphasizing hypotaxis while the latter focusing on parataxis, the translator tries to break the complicated long English sentences into short coherent Chinese sentences and sometimes makes necessary adaptations in the order of sentences in order to conform to the reading habit of Chinese readers. For example, "The self-aware movement for religious reform, which emerged in the nineteenth century, appeared only after profound changes had taken place in the external situation of the Jews and in their understanding of themselves” (Meyer, 1988, p. 10). The original sentence is a complicated sentence inserted by an unrestrictive attributive clause introduced by which and followed by an adverbial clause of time led by after. The translator first cuts this whole sentence into two parts with the main clause and the attributive clause as the first part and the adverbial clause as the second one. Retaining the original meaning intact, the translator then makes two adaptations in the sequence in terms of expression: the time in the attributive clause acts as the subject of the first part while the second part is transformed into subject-verb-object pattern by picking out a logic subject from the original adverbial clause of time. All these treatments are intended to meet with the reading habit of Chinese readers. The final version of this sentence is “19世纪发生了以宗教改革为目的的觉醒运动, 犹太人所处的外部局势以及他们对自身情 况的理解都发生了深刻的变化。”

\section{Textual level}

As for the text-level, Peter Newmark (2011) pointed out the importance of revision in the procedure of translation as "spend on revising $50-70 \%$ of the time you took on translating, depending on the difficulty of the text” (p. 37). As Response to Modernity constitutes largely complicated long sentences, the first version turns out to be unsatisfactory from a textual perspective. The translator spends more than half of the mid-translation's time on revision in the course of post-translation. The guiding principle for revising the first draft is laid down from the textual consideration. The revised version aims for a cohesive and coherent whole conforming to the 
intelligibility of target language readers. According to Beaugrande (1981, p. 6), "coherence is clearly not a mere feature of texts, but rather the outcome of cognitive processes among text users.” From the perspective of Chinese readers' cognitive mindset, the translator adopts specific methods to fulfill the intra-textual and inter-textual coherence of the whole version. The following two paragraphs serve as examples.

In their quest for equal rights, a few French Jews went out of their way to state publicly that their religion did not conflict with the duties of citizenship. They minimized the practical significance of the messianic return to Palestine, declaring in a petition to the National Assembly that Jews believed only the dogmas of natural religion and practiced only three principal rites: circumcision, Sabbath, and festivals. As in Germany, some French Jews preferred to think of their faith as simply the "religion of Moses." The years following the Revolution were religiously devastating for the newly emancipated Jews of France. During the Terror and the Thermidorian reaction a virulent campaign directed against all religions made it difficult or even dangerous for Jews to attend synagogue, keep the Sabbath, and provide themselves with kosher meat. A few became fervent advocates of the revolutionary "cult of reason" and for the first time there were mixed marriages. Napoleon's restoration of the Catholic Church, through a concordat with the pope in 1801, therefore came as welcome relief to the faithful. Jews were grateful to Bonaparte for reestablishing religion in France. But the subservient position now assigned to Catholicism, and even more to Protestantism, within the centralized absolutistic Napoleonic state was bound to lead sooner or later to a similar subjugation of Jewish institutions. (Meyer, 1988, p. 27)

The first version is nearly a literal translation to reproduce the original meaning word for word.

为追求平等权利, 一些法裔犹太人特意公开宣布其宗教并不与公民的职责相冲突。他们尽量地降低弥赛亚回 归巴勒斯坦的实际重要性，向国民议会递交请愿书宣称犹太人只相信自然宗教，只遵循三个主要的仪式：割礼、 安息日以及各个节日。像德国的情况一样, 一部分法裔犹太人愿意将自己的信仰认为只是 “摩西的宗教。”大革 命之后对于刚刚被解放的法国犹太人来说，宗教上遭遇了毁灭性的打击。恐怖时期和热月政变时期，发动了一场 反对所有宗教的运动, 犹太人去教堂做礼拜、守安息日, 给自己供应洁净肉食都面临着重重困难, 甚至是危机四 伏。一些人转而积极拥护革命的 “理性宗派, ”通婚现象也首次发生。拿破仑 1801 年与教皇达成协定恢复了天主 教堂, 受到了忠实者们的欢迎。犹太人感激拿破仑在法国重建宗教。但是在这个中央集权拿破仑专制的国度里, 天主教和新教的地位一个比一个更低, 迟早要导致对犹太机构的镇压。

After reading the whole paragraph, readers cannot grasp the original writer's intention. In the process of revising, the translator tries to dig out the deep meaning between lines that the original author intends to categorize three groups of French Jewry with their respective change in Jewish belief. By elaborately dealing with such common phrases as "a few ... some ... a few," the translator emphasizes on the cohesiveness of these intra-textual markers to make prominent three groups of French Jewry. The revised version is like this

为追求权利的平等, 有的法裔犹太人特意公开宣布其宗教与公民的职责并不冲突。在对待弥赛亚回归巴勒斯 坦的问题上，他们尽量减少问题的实际重要性，向国民议会递交了请愿书，宣称犹太人只信奉自然宗教，并遵循 三种主要仪式: 割礼、安息日及其它节日。也有一部分法裔犹太人愿意将自己的信仰视为 “摩西宗教, ”这种情 况与德国很相似。大革命之后对于刚刚获得解放的法国犹太人来说, 宗教上遭遇了毁灭性的打击。恐怖时期和热 月政变时期, 他们发动了一场反对所有宗教的运动, 犹太人去会堂做礼拜、守护安息日, 供应洁净肉食都面临着 重重困难，甚至是危机四伏。除此之外，还有一些人转而积极拥护革命的“理性宗派，”通婚现象也首次发生。 1801年, 拿破仑与教皇达成协议恢复了天主教堂, 得到了天主教信徒们的热烈拥护。拿破仑在法国重建宗教, 犹 太人感激不尽。但是在这个中央集权化的国度里, 天主教臣服于拿破仑的专制之下, 新教的地位更低, 因此犹太 机构迟早要被遏制。

By adding “也” (also) to the second marker and “除此之外, 还有” (apart from these, there are some other) to the third, the revised version can help the readers of target language easily grasp the original work's essence on one hand and promote the textual cohesiveness on the other. 
In France itself the two assemblies did not generate a profound rethinking of Judaism or an impetus to principled cultic reform. In 1808, a decree establishing a consistory system organized all of French Jewry under the watchful eye of the government. The new centralized hierarchy, composed of rabbis and laymen, proved to be conservative in religious matters except where citizenship was directly involved.

However, a similar structure could also be used to institute and supervise a coherent program of reform. And this indeed became a principal aim of the consistory which was established that same year for the Jews living in the French-controlled Kingdom of Westphalia. (Meyer, 1988, p. 28)

The first version is:

法国的两次集会并没有发起对犹太教的深刻反思, 也没有产生有原则的宗教改革动力。1808年颁布法令建立 宗教法院体质，将所有法裔犹太人组织起来受政府的监管。新的中央集权等级制主要由拉比和外行人组成，除涉 及到公民权的情况之外，在宗教事务方面表现地很保守。

然而, 另外一个类似的组织也能制定并监管极具凝聚力的改革方案。这的确成为了为生活在法国管辖的西伐 利亚（Westphalia一德意志联邦共和国西北部地区）的犹太人而建立的宗教法院的主要目标。

In the process of revising, the author finds that the first version is not smooth or readable. The very reason lies in the understanding of the relationship between these two paragraphs. They are not isolated individually, but related to each other by means of the beginning expression in the second paragraph "however, a similar structure." The word "however" in the very beginning of the second paragraph shows that there is a turning point shifted from the previous text while the word "similar" shows that the "structure" appearing in the second paragraph must be close to the one mentioned in the first paragraph. As for the exact denotation of "structure," the translator needs to seek reference in the first paragraph. To sum up, these two paragraphs should be rendered as a coherent whole. Obviously, the first version does not produce the coherent effect between the two paragraphs. By further analysis, the referential meaning of "structure" is equal to "consistory" of the first paragraph. These two paragraphs introduce two similar consistories established in the same year with in the native France and the other in the French-controlled Kingdom of Westphalia. The faithful rendering of "similar" in the first version is not an idiomatic expression for Chinese readers. According to Prof. Huang Zhonglian's (2000) variation theory, the translator makes some adjustment in the expression to enhance the idiomatic quality of the version on the basis of keeping the original meaning unchanged. Four-character phraseology is an effective means to fulfill this goal. The revised version is as followings:

法国召集的这两次会议并没有引发人们对犹太教进行深刻反思，也没有产生有原则的宗教改革动力。1808年， 法国政府颁布法令建立宗教法院机构, 将所有的法裔犹太人纳入政府的监管范围之内。新的中央集权等级制主要 由拉比和普通信徒组成，除涉及到公民权的情况之外，宗教法院机构在处理宗教事务时非常保守。

无独有偶, 在同一年, 隶属于法国的威斯特法利亚王国（Westphalia: 德意志联邦共和国西北部地区）也成立 了犹太宗教法院, 该机构成立的主要目的是制定并监管统一的改革方案。

The above two examples show how to achieve inter-textual cohesiveness and inter-textual coherence in terms of the translation of paragraphs. As the original work covers nearly 500 hundred pages, this great length reveals the importance of textual approaches to translation. As a matter of fact, the translator spends much time on fulfilling textual cohesion and coherence in the process of revising the translation.

\section{Conclusion}

Eugene Nida (1998, p. 308) once mentions that "for truly successful translating, biculturalism is even more important than bilingualism, since words only have meanings in terms of the cultures in which they 
function.” In that sense, the translator regards translation as not merely a linguistic shift between two languages but rather a cross-cultural communication between two cultures. In the process of translating Michael Meyer's Response to Modernity, the translator tries to make up for cultural information geographically, historically, and religiously, and furthermore to enhance the textual cohesion and coherence at a macro level. The adoption of different translating strategies embodies the translator's subjectivity on one hand and increases the readability of the translation on the other. The guiding principle of translation includes faithfulness and expressiveness: to be faithful to the original work and to produce expressive renderings for the target language readers.

\section{References}

Beaugrande, R. (1980). Text, discourse, and process. Longman: Longman Group Ltd.

Buber, M. (2002). On Judaism (J. LIU et al., Trans.). Jinan: Shandong University Publishing House.

Chen, T. (2013). The Arab world and the palestine question. Beijing: World Knowledge Publishing House.

Cohen, A. (1998). Everyman's Talmud (X. GE, Trans.). Jinan: Shandong University Publishing House.

Fang, M. (2003). A dictionary of translation studies. Shanghai: Shanghai Foreign Language Education Press.

Gao, Y. et al. (2002). A dictionary of English surnames and Christian names. Beijing: Foreign Language Teaching and Research Press.

Huang, Z. (2000). Studies in variation translation. Beijing: China Foreign Translation Publish House.

Kaplan, M. M. (2002). Judaism as a civilization (F. W Huang et al., Trans.). Jinan: Shandong University Publishing House.

Meyer, M. A. (1988). Response to modernity: A history of the reform movement in Judaism. New York, Oxford: Oxford University Press.

Newmark, P. (2001). A textbook of translation. Shanghai: Shanghai Foreign Language Education Press.

Nida, E. A. (1998). Language, culture and translating. Hohhot: Inner Mongolia University Press.

Roth, C. (1997). A short history of the Jewish people (F. W Huang et al., Trans.). Jinan: Shandong University Publishing House.

Rudavsky, D. (2000). Modern Jewish religious movements: A history of emancipation and adjustment (Y. D. Fu, Trans.). Jinan: Shandong University Publishing House.

Xu, X. \& Ling, J. Y. (1993). Encyclopedia Judaica. Shanghai: Shanghai People’s Publishing House.

Xu, X. (2015). Antisemitism: Past and present. Beijing: People’s Publishing House.

Zhou, X. F. (2004). Dictionary Judaica. Shanghai: Shanghai Lexicographical Publishing House. 